\title{
THE EFFECTS OF OSCILLATING NOZZLE ON CHRISTIANSEN'S UNIFORMITY COEFFICIENT
}

\author{
Ognjen Gabrić, Dušan Prodanović, Jasna Plavšić
}

Original scientific pape Rainfall simulators have been used in research for more than 40 years. Unfortunately, there is not much literature on their construction and calibration. This paper presents a rainfall simulator experimental rig, developed at the Faculty of Civil Engineering in Subotica, and its calibration, i.e. determination of rainfall distribution over the surface. The simulator uses six VeeJet 80100 oscillating nozzles equally spaced with $100 \mathrm{~cm}$ distance along a horizontal pipe. A box for rainfall intensity reduction is placed under each nozzle. The maximum rainfall intensity that can be achieved is $3,1 \mathrm{~mm} / \mathrm{min}$ and maximum surface covered by the simulator is $1 \times 6 \mathrm{~m}^{2}$. As a measure of uniformity of rainfall distribution over the surface, the Christiansen's uniformity coefficient was used. For surface widths ranging from 0,1 to $1 \mathrm{~m}$, the Christiansen's coefficient varies from 0,8 to 0,9 for the oscillating nozzles, while for the nonoscillating nozzle it has a value of 0,46 .

Keywords: oscillating nozzle; rainfall simulator; uniformity coefficient

Doprinos osciliranja sapnice Christiansenovom koeficijentu ravnomjernosti

Izvorni znanstveni članak

Simulatori kiše su rabljeni u istraživanjima već više od 40 godina. Nažalost, literatura koja se bavi njihovim razvojem i kalibriranjem je oskudna. U radu je prikazana konstrukcija i kalibriranje, odnosno utvrđivanje raspodjele kiše po površini, za simulator kiše razvijen na Građevinskom fakultetu u Subotici. Simulator rabi šest VeeJet 80100 oscilirajućih sapnica jednako raspoređenih duž horizontalne cijevi na međusobnoj udaljenosti od $100 \mathrm{~cm}$. Kutija za smanjenje intenziteta kiše se nalazi ispod svake sapnice. Maksimalni intenzitet kiše koji se može postići simulatorom je 3,1 mm/min, a maksimalna površina pod simulatorom je $1 \times 6 \mathrm{~m}^{2}$. Kao mjera ujednačenosti raspodjele kiše po površini rabljen je Christiansenov koeficijent ravnomjernosti. Za oscilirajuće sapnice i površine širine od 0,1 do $1 \mathrm{~m}$, Christiansenov koeficijent varira od 0,8 do 0,9 . Za neoscilirajuće sapnice koeficijent ima vrijednost od 0,46 .

Ključne riječi: koeficijent ravnomjernosti; oscilirajuća sapnica; simulator kiše

\section{Introduction}

Rainfall simulators are used in laboratory studies, in controlled conditions of drainage process, erosion or infiltration. Even though they have an advantage of controlling the rainfall intensity, rainfall depth and duration, it is not an easy task to reproduce all characteristics of natural rainfall. A well-designed simulator is expected to reproduce several features of natural rainfall: 1) raindrop size, 2) velocity, 3) uniform rainfall intensity, 4) uniform rainfall distribution over the ground surface.

Raindrop size and uniform rainfall intensity are achieved by choosing an adequate nozzle type and the water pressure at the nozzle. Long and Demars [1] presented the results of Meyer's research who came to the conclusion that the nozzles of the American Spraying Systems Company, trademarks VeeJet 80100, VeeJet 8070, VeeJet 80150, FullJet 106SQ and FullJet 50SQ, with the 0,41 bar nozzle pressure, can be used in rainfall simulators. Other researchers also used the same nozzles on their simulators [2]. The nozzles of the same manufacturer, type FullJet $1.5 \mathrm{H} 30$ and $1 \mathrm{HH} 12$, were used by Pall [3] with the pressure of 0,48 bar. Blanquies, Scharrf and Hallock [4] presented the rainfall simulator developed for the United States Department of Agriculture (USDA). The rainfall simulator consists of VeeJet 80100 nozzles which make $2 \div 3 \mathrm{~mm}$ raindrop size under the nozzle pressure of 0,4 bar.

Raindrop velocity and vertical falling on the surface are achieved by placing the nozzles at certain height from the surface [5]. The elevation has to be appropriate for the big drops to slow down and small ones to reach constant velocity. The elevation also has to be high enough for raindrops leaving the nozzle at an angle to fall down vertically on the surface. This elevation depends on the type of nozzle and it varies from $1,83 \mathrm{~m}$ [6], over $2,44 \mathrm{~m}$ [2], to 3,00 $\mathrm{m}$ [4] from the horizontal surface.

The main problem of any rainfall simulator is that nozzles produce far higher rainfall intensity than that of natural rainfall, even with the small nozzle pressure [7]. Therefore it is necessary to reduce rainfall intensity, and this is achieved by reducing the time of surface exposure to the artificial rain spray.

Hudson [2] presents the solutions of several researchers. Meyer places the nozzles on an overhead carriage that moves back and forth and the water flow is stopped by solenoid valves. The maximum rainfall intensity of that simulator was $127 \mathrm{~mm} / \mathrm{h}$. Swanson placed the nozzles on the platforms that were parallel to the ground and they rotated around a vertical axis, thus reducing the rainfall intensity. The rotating disc solution presented by Morin, Goldberg and Seginer was very popular and later developed in many countries. A still nozzle is releasing spray constantly, but the surface beneath is periodically protected by a metal disc which is rotated around a horizontal axis. The spray goes through the opening in the disc when it is under the nozzle. Pall [3] modified the rotating disc simulator by using two discs. On the USDA simulator [4] the rainfall intensity is controlled by the frequency of nozzle crossing over the opening in the box, i.e. by the time nozzle is kept outside the hole in the box.

A simulator should also provide uniform rainfall distribution over the surface. While analyzing the influence of nozzle spacing in irrigation systems on water 
distribution over the surface, Christiansen [8] introduced the uniformity coefficient $u$ defined as:

$$
u=1-\left(\frac{\sum\left|x_{i}-x_{\mathrm{avg}}\right|}{\sum x_{i}}\right)
$$

Where $x_{i}$ is volume of water in an individual container, and $x_{\text {avg }}$ is average volume of water from all containers.

For the ideal spatial rainfall distribution, value of Christiansen's coefficient is 1 .

The simulator developed by Pall [3] had Christiansen's uniformity coefficient in the range $0,85 \div$ 0,95 , depending on the surface dimensions, while the simulator developed on the Imperial College in London [6] had the uniformity coefficient 0,8 .

Although the rainfall simulators are widely used, there is a lack of literature about their construction and calibration. The aim of this study is to present the results of methodology used for checking the Christiansen's uniformity coefficient of the rainfall simulator developed at the Faculty of Civil Engineering in Subotica. Christiansen's uniformity coefficient is determined depending on the surface size in case of a fixed nozzle and a nozzle oscillating above the box with an opening. The nozzle type is VeeJet 80100, manufacturer Spraying Systems Co.

\section{Simulator design}

The simulator uses six VeeJet 80100 nozzles placed on a horizontal pipe with the $50 \mathrm{~mm}$ diameter and the $6 \mathrm{~m}$ length. Due to the slow water velocities, the specified pipe diameter allows constant water pressure of $0,4 \mathrm{bar}$ in all nozzles. Water supply connection is located at the middle of the pipe, between nozzles 3 and 4 (Fig. 1).

The nozzles are located at equal spacing of $100 \mathrm{~cm}$ and $4,5 \mathrm{~m}$ above the surface in its horizontal position. The nozzles are elevated slightly higher than those described in the literature so that the experiments with steep surface slope can be performed as well. With such elevation, there is enough time for raindrops to reach the constant velocity and fall vertically onto the surface.

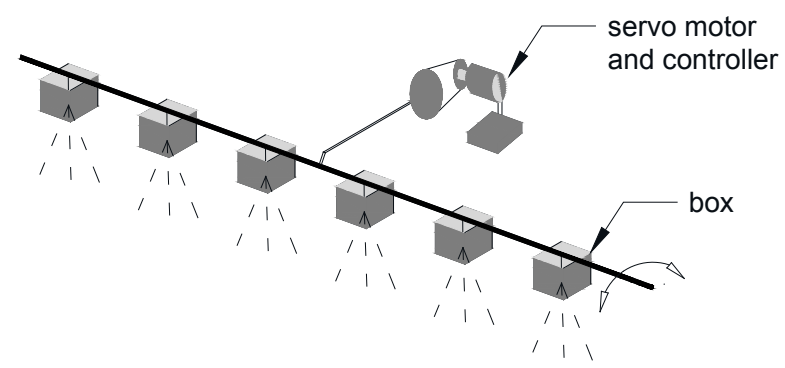

Figure 1 Rainfall simulator

A box for rainfall intensity reduction is placed under each nozzle (Fig. 2). The box dimensions are $0,4 \times 0,4 \times$ $0,2 \mathrm{~m}$. Its upper side is fully open, while the lower side has three holes. Water coming out from the nozzles falls down through the central square hole $0,16 \times 0,16 \mathrm{~m}$. The other two smaller circular holes are used to drain excess water from the box back into the tank.

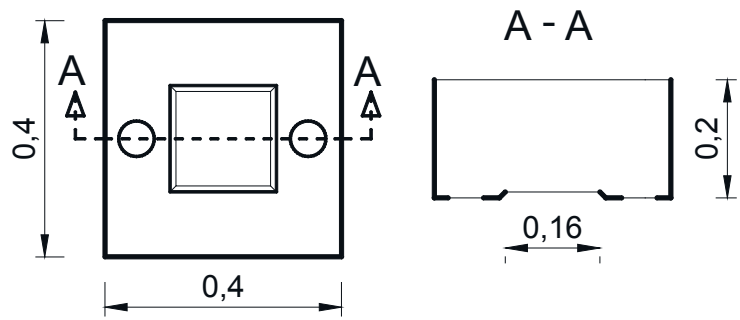

Figure 2 The box for reducing the rainfall intensity

Capacity of the water supply tank is 500 liters. Using the centrifugal pump, water is conveyed from the tank to the pipe with nozzles. The system pressure is controlled by the valves placed downstream from the pump.

The system for controlling the rainfall simulator includes servo motor, controller and two sprocket wheels with the chain. This system enables oscillatory movement of nozzles for $\pm 45^{\circ}$ (Fig. 3), thus enabling adjustment of rainfall intensity by changing time during which the nozzle is not covering central hole.

Before the beginning of each experiment, until the system pressure is stabilized, the nozzles are placed in the farthest position in which water cannot fall on the surface (Fig. 3a). With nozzles in this position water spray does not go through the central hole, but goes through the gutter that conveys water back to the tank. When the system pressure is stabilized at 0,4 bar, the engine that rotates the pipe is started by the controller. Rotation of the pipe moves the nozzle, which travels above the central hole (Fig. 3b) and stops at the other end position. The time nozzle spends in the farthest positions determines the intensity of rain falling on the experimental surface.
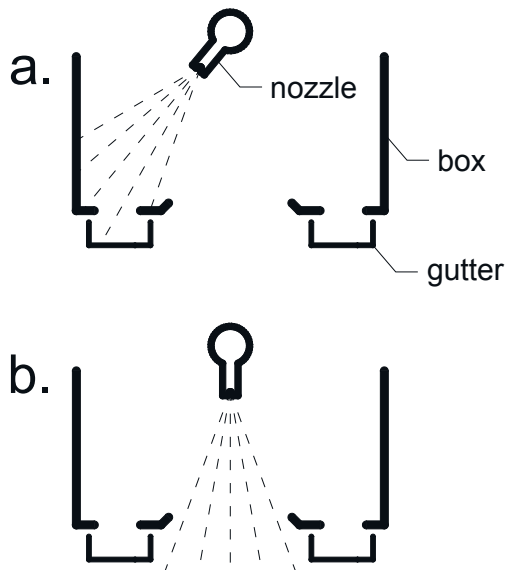

Figure 3 a) the farthest position of a nozzle, b) working position of a nozzle

By oscillating the nozzle above the box, this simulator can produce maximum rainfall intensity of 3,1 $\mathrm{mm} / \mathrm{min}$, which generally covers the highest rainfall intensities occurring locally (according to Zelenhasic [9], intensities of 10-minute storms of 100 years return period in Serbia range up to $3,5 \mathrm{~mm} / \mathrm{min}$ ).

Maximum surface covered by the simulator is $6 \mathrm{~m}^{2}$.

\section{$3 \quad$ Nozzle testing}

In phase 1 , the water spray intensity of all six VeeJet 80100 nozzles was tested. It was found that the rainfall 
intensity produced by one non-oscillating nozzle with the 0,4 bar pressure ranges from 14,2 to $14,5 \mathrm{~mm} / \mathrm{min}$.

Each nozzle has been tested separately to establish water distribution over the surface. Containers of $5 \mathrm{~cm}$ in diameter were placed on the $1 \times 1 \mathrm{~m}$ surface under the nozzle. After stabilizing the pressure, the water has been accumulated in containers for 5 minutes. The water distribution over the surface was determined by measuring the mass of water in each container. Figure 4 presents distribution of water on the unit surface from one nozzle for rainfall intensity of $3,1 \mathrm{~mm} / \mathrm{min}$ over 5 minutes. This distribution is shown relative to the maximum water mass in a single container.

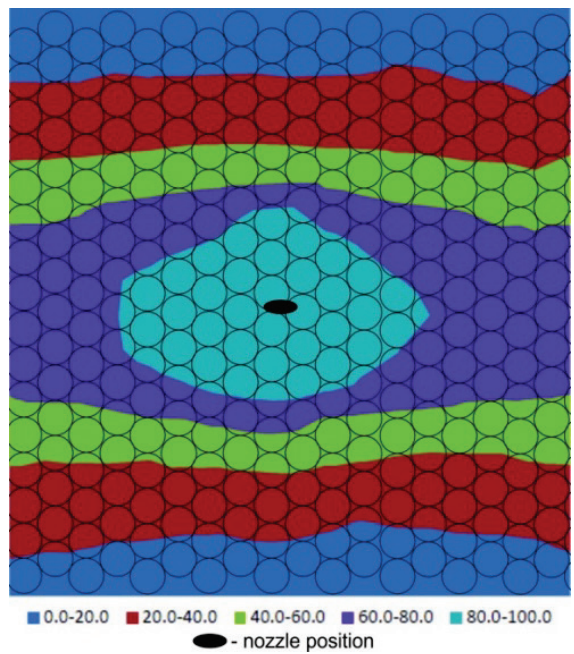

Figure 4 Distribution of water from one nozzle over the $1 \times 1 \mathrm{~m}$ surface during 5 minutes (in \% of the maximum water mass in container)

Change in water volume on the surface is more pronounced in transverse direction than in longitudinal direction due to an elliptical shape of the nozzle hole. Christiansen's uniformity coefficient varies from 0,46 for the $1 \mathrm{~m}$ wide surface, to 0,9 for the $0,1 \mathrm{~m}$ wide surface (Fig. 5). The length of the surface is $1 \mathrm{~m}$.

The oscillating of the nozzle above the box is introduced in order to increase the value of Christiansen's coefficient and decrease high rainfall intensities.

Water distribution over the surface for one oscillating nozzle is determined in the same way as for the nonoscillating, fixed nozzle. Christiansen's uniformity coefficient varies within the range $0,8 \div 0,9$ for the surface widths in the range $0,1 \div 1 \mathrm{~m}$ (Fig 5 ). The length of the surface is $1 \mathrm{~m}$.

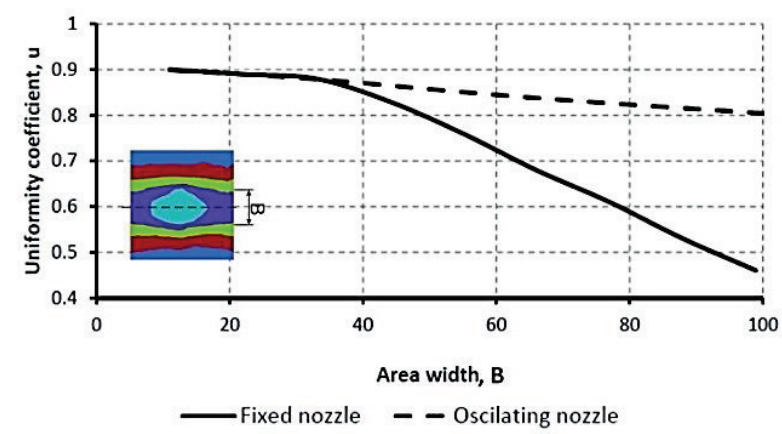

Figure 5 Christiansen's coefficient for fixed and oscillating nozzle

Water distribution on the surface of $6 \times 1 \mathrm{~m}$ with 6 oscillating nozzles and $100 \mathrm{~cm}$ distance between them is determined as well for the same rainfall intensity of 3,1 $\mathrm{mm} / \mathrm{min}$ (Fig. 6). In this case Christiansen's uniformity coefficient is 0,8 . Since the rainfall intensity is regulated by the time the nozzle is kept in the side position, it is reasonable to assume that the water distribution over the surface would follow the same pattern for other intensities as well.

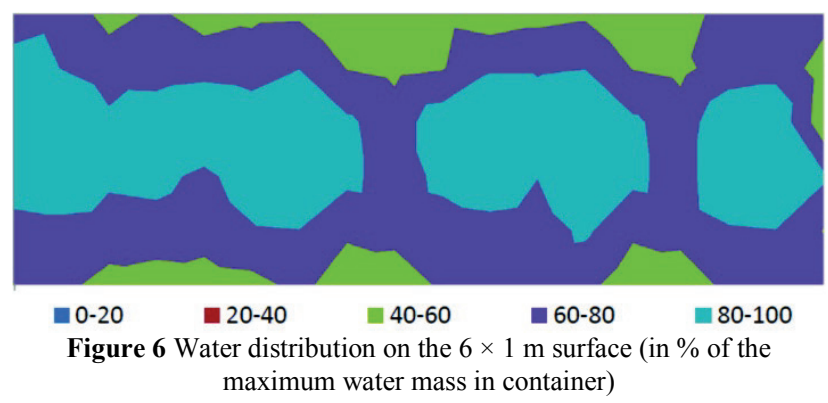

\section{Discussion}

Christiansen's uniformity coefficient for fixed nozzle VeeJet 80100 tested in this study varies from 0,46 for the $1 \mathrm{~m}$ wide surface, to 0,9 for the $0,1 \mathrm{~m}$ wide surface. For the surface width of $0,5 \mathrm{~m}$ the coefficient is 0,8 and this is considered as good distribution. However, rainfall intensity for the fixed nozzle is too high (14,2 to 14,5 $\mathrm{mm} / \mathrm{min}$ ) for performing hydrological experiments.

It is possible to achieve the intensity of a natural rainfall by blocking the nozzle spray with the box and oscillating the nozzle above it. In that case, uniformity coefficient varies within the range $0,8 \div 0,9$ for the surface width in the range $0,1 \div 1 \mathrm{~m}$ wide.

Using several nozzles simultaneously provides larger surface for experiments with relatively uniform rainfall spatial distribution. For the surface of $6 \times 1 \mathrm{~m}$ uniformity coefficient is 0,8 .

\section{Conclusions}

The rainfall simulator has been developed at the Faculty of Civil Engineering in Subotica. It has VeeJet 80100 nozzles and it works by the principle of oscillating nozzle above the box with the hole. The nozzles are placed $100 \mathrm{~cm}$ away from each other, elevated 4,5 $\mathrm{m}$ from the horizontal surface and they work under the pressure of 0,4 bar.

In comparison to the cited literature, the chosen nozzle meets the terms to form the necessary raindrop size, while the nozzle elevation from the surface satisfies the criteria for achieving constant drop velocity and vertical falling of drops.

Maximum rainfall intensity produced by each nozzle is 14,2 to $14,5 \mathrm{~mm} / \mathrm{min}$. Christiansen's uniformity coefficient for the $1 \times 1 \mathrm{~m}$ surface and fixed nozzle is $u=0,46$. This result is new compared to the cited literature.

The rainfall intensity reduction is achieved by placing the box with the hole under the nozzles and oscillating the nozzle above it. In this case Christiansen's coefficient varies from 0,8 to 0,9 for the surface width ranging from 0,1 to $1 \mathrm{~m}$. For a ten-minute-rainfall on the $6 \times 1 \mathrm{~m}$ 
surface, Christiansen's uniformity coefficient is $u=0,8$, which is in compliance with results from literature.

Maximum rainfall intensity achieved by this simulator is $3,1 \mathrm{~mm} / \mathrm{min}$.

Further research should be conducted in order to test the influence of the surface size on the results obtained from experimental installations with rainfall simulators.

\section{Acknowledgement}

This study was funded by the Serbian Ministry for Science; project TR37010 "Stormwater Drainage Systems as Part of Urban and Traffic Infrastructure".

\section{References}

[1] Long, R. P.; Demars, K. R. Design Considerations for a Prototype Erosion Control Testing Plot. // The New England Transportation Consorcium, University of Connecticut, 2005.

[2] Hudson, N. W. Field Measurement of Soil Erosion and Runoff. // FAO Soils Bulletin 68, Food and Agricultural Organization of United Nations, Vialledelle Terme di Caracalla, Rome, Italy, 1993.

[3] Pall, R.; Dickinson, W. T.; Beals, D.; McGirr, D. Development and Calibration of a Rainfall Simulator. // Canadian Agricultural Engineering. 25, 2(1983), pp. 181187.

[4] Blanquies J.; Scharrf M.; Hallock B. The Design and Construction of a Rainfall Simulator. // International Erosion Control Association (IECA), 34 ${ }^{\text {th }}$ Annual Conference and Expo / Las Vegas, Nevada, 2003.

[5] Gabrić, O.; Plavšić, J.; Prodanović, D. Izrada i provera performansi simulatora kiše. // 16. naučno savetovanje SDHI i SDH, Knjiga apstrakata / Donji Milanovac, 2012, pp. 252-257 (in Serbian).

[6] Hall, M. J.; Johnston, P. M.; Wheater, H. S. Evaluation of overland flow models using laboratory catchment data, I. An aparatus for laboratory catchment studies. // Hydrological Sciences Journal. 34, (1989), pp. 277-288. DOI: 10.1080/02626668909491335

[7] Elwell H. A.; Makwanya H. Design and calibration of a rainfall simulator nozzle assembly for laboratory and field studies. Res. Bulletin 25, Dept. of Agricultural Technical and Extension Services, Zimbabwe, 1980.

[8] Christiansen J. P. Irrigation by sprinkling. Bulletin No 670, University of California Agricultural Experiment Station, USA, 1942.

[9] Zelenhasić, E. i Ruski, M. Inženjerska hidrologija. Naučna knjiga, Beograd, 1991 (in Serbian).

\section{Authors' addresses}

Ognjen Gabrić, M.Sci.

Faculty of Civil Engineering Subotica

Kozaracka 2a, 24000 Subotica, Republic of Serbia

E-mail: ogabric@gmail.com

\section{Dušan Prodanović, Ph.D.}

Faculty of Civil Engineering Belgrade

Bulevar Kralja Aleksandra 73, 11000 Beograd, Republic of Serbia

E-mail: eprodano@hikom.grf.bg.ac.rs

\section{Jasna Plavšić, Ph.D.}

Faculty of Civil Engineering Belgrade

Bulevar Kralja Aleksandra 73, 11000 Beograd, Republic of Serbia

E-mail: jplavsic@grf.bg.ac.rs 